\title{
Document on Buying Gethsemane Garden by Three Brothers from Bosnia in 1681 - Text and Context
}

\author{
Dokument o nakupu vrta Getsemani s strani treh \\ bratov iz Bosne leta 1681 - besedilo in kontekst
}

\begin{abstract}
This paper presents a document dating from 1681 (1092 Hijra year): the document confirms the sale and endowment of fig and olive seedlings as well as the other properties on the land of Madrasa al-Salähiyya in Jerusalem, which was implemented by the means of the so-called al-hikr. The brothers from Sarajevo, Pavle, Jakov and Antun, purchased this particular property and bequeathed it to the Franciscan monks who lived in the monastery al-'Amüd (Monastery of the Holy Saviour) in Jerusalem and to the poor Christians that required alms. The curious issue in this case is the prevailing opinion of scholars that the space that is the subject of the sale in this document is the space of Gethsemane garden, one of the most important Christian holy sites.
\end{abstract}

Key words: Gethsemane Garden, brothers Branković (Brajković), Franciscans, Jerusalem, waqf, Madrasah al-Ṣalähịya

Povzetek: Članek predstavi dokument iz leta 1681 (1092. leto hidžre): dokument potrjuje prodajo in nadarbino sadik fig in oliv ter druge lastnine zemlje Madrasa al-Ṣalāḥiyya v Jeruzalemu, ki je bila urejena s takoimenovanim al-hikr. Bratje iz Sarajeva, Pavle, Jakov in Antun, so kupili to zemljo in jo nato zapustili frančiškanskim menihom, ki so živeli v samostanu al-'Amūd (samostan Svetega Rešenika) v Jeruzalemu, in ubogim kristjanom, ki so potrebovali miloščino. Pri tem je zanimivo, da večina strokovnjakov meni, da je prostor, ki je predmet pogodbe, vrt Getsemani, eden najpomembnejših krščanskih svetih krajev.

Ključne besede: vrt Getsemani, bratje Branković (Brajković), frančiškani, Jeruzalem, waqf, Madrasah al-Șalāhiiyya

\section{Madrasah al-Ṣalāḥiyya and its endowment}

After it was reconquered by Șalāḥuddīn al-'Ayyūbī (1137-1193) in 1187 , Jerusalem remained practically empty. Endowment of facilities 
in Jerusalem also meant revival and resettlement of the city. Ṣalāhuddinn al-'Ayyūbī endowed a Sufi hanikah (al-Hānaqāh al-Șalāḥiyya) in 1189/585 AH, a hospital (al-Bìmārastān al-Salāhì) which became functional only after his death (Frenkel 1999, 5), and a madrasah in the year 1180/575 $\mathrm{AH}$, which was also named after its founder, al-Madrasa al-Salāhiyya. Occasionally, this madrasah is also called al-Nāșiriyya or al-Salāhiyya al-kubrā (Ibn Wāṣil 1957, 407). Șalāḥuddīn established it as "a madrasah following the Shafi'i madhab education of scholars (al-fuqah $\bar{a}^{\prime}$ ), who will reside in it and be devoted only to science and who will be known as those committed to the good (al-ma'rūfin bi al-șalāh)«(al-Subkī s.a., 126).

Madrasah al-Ṣalāhiyya was situated in the Church of Saint Anne, ${ }^{1}$ one of the oldest structures which served as a pagan shrine during the Roman period, then as a Byzantine basilica dedicated to Saint Anne, the mother of Virgin Mary, and finally as the Catholic Church of St Anne, built by the Crusaders in 1140 (Pringle 2007, 142-156). Some authors believe that Șalāhuddīn turned it into a madrasah, thus returning the original purpose to the structure that had stood there before the church (Pringle 2007, 143). It is possible that the Byzantine basilica was pulled down by the Fatimid caliph al-Hākim in 1009 and that, in its place, there stood a Shafi'i madhab madrasah (al-madhab al-ša fi $i^{`}$ ) (Boas 2001, 115) during the period of Seljuq dynasty. In the crypt of the Church of St Anne there is a cave believed to be the birthplace of the Virgin Mary. Even though the building of the Church of St Anne was turned into a madrasah, Christians were permitted to enter the cave underneath it and pray. A document from the records of the Sharia Court in Jerusalem is related to this exact permission. Namely, representatives of the Franciscan Monastery in Jerusalem (Dayr al-'Amüd) complained to Istanbul that, among other things, they and other visitors were charged a fee for entering the cave situated below the garden of the al-Ṣalāhiyya madrasah and accessible by stairs, where they performed their prayers, disturbing no one in the process. Witnesses thereto were Sheikh Yāsin, Shafi'i Mufti, Muderris and the administrator of the waqf (nāzir) of the Madrasah al-Ṣalāhiyya who verified the agreement in the purchase document stating that the Branković brothers purchased the Gethsemane

1 Arab sources record it as هنح دنص (Ibn Wã il, op. cit., t. 2, 405), and occasionally as هنح دي (al-Subkï, op. cit., 126.). 
Garden, and 'Uțmān Ibn Muhammad, gatekeeper of the madrasah. On this ground, the Sultan ordered that they be allowed to visit the cave, without being disturbed by anyone. ${ }^{2}$

\subsection{Translation of the body text of the document and of the verification texts}

The verification text on the left-hand side of the document reads the following:

The content of this document, upon my inspection, is authentic. The authenticity of its content has been confirmed before me.

Standing in need of forgiveness from the Lord Almighty, I am Zufar Ibn

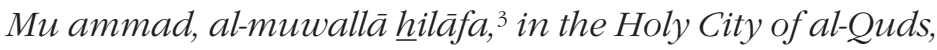

May they be forgiven. ${ }^{4}$

Below the verification text there is a round seal reading the following:

My success depends on Allah alone and on Him alone I do rely.

God's servant Zufar.

The verification text on the right-hand side of the document reads the following:

This is a verified copy, the authenticity of which is confirmed by - so that it can be used to act upon pursuant to Sharia regulations, considering that its truthfulness is established against the court records and by a confirmation given in verbal testimony - standing in need of the mercy and help of Allah, the Exalted, Ibrahim al-na' 'ib' in the Holy City of al-Quds.

Below the verification text there is a round seal reading the following: Ibrāhìm al- $\underline{\text { Ha}} \bar{a} l i d \bar{\imath}$

The year of $1187 / 1773$

2 Siğill Ma kama al-Quds al-šar'iyya, No. 183 (2), 1091 AH/1680, 228. As quoted in: Ruwayda Fa $1 \mathrm{~A}$ mad A mad, al-Madrasa al-alā iyya fí al-Quds (336-588 AH/1192-1918), an unpublished Master's thesis defended at the al-Nağā State University in al-Nābulus, 2015, 25.

3 Deputy qadi of Jerusalem, following the Hanafi Madhab.

4 Referring to Zufar and his father Muhammad.

5 Deputy qadi. 
The verification text on the right-hand margin reads the following:

Praise be to Allah alone.

This is a truthful verified copy.

The verification is written by humble Yāsin, mufti and administrator of the Madrasah al-Salāhiyya.

Below the text there is a round seal reading Yäsin, with the rest of the text being illegible.

The bottom of the right-hand margin reads "qayd šudda", which is an expression that scribes or copyists used to indicate that a text is finished or complete.

Translation of the body text:

This is an authentic and Sharia-based document on purchase and endowment, the content of which is known on the basis of what transpired and what was effected and written down in the session of the Illustrious Sharia Court in the Protected City of al-Quds, highly elevated and endowed with purity, as elevated by Allah, the Elevated One above all things.

Before our leader and dignitary, an illustrious adornment of all qadis and teachers, the pillow of scholars and committed students, the leader of dignitaries and true apprehenders, the resolver of religious quandaries, the esteemed Sharia judge whose handwritten signature stands above the text, may his excellence and high esteem be long-lasting, the purchaser haji 'Ali - the pride of his peers and delight of his friends, son of late shaikh Yüsuf al- azraği ${ }^{6}{ }^{\circ}$ of the lineage the nobility of which is well known, as a Sharia plenipotentiary on behalf of Pavle and his brother Jakov, sons of Agustin, who are Christians from the town of Bosna-Saraj [Sarajevo] and whose [haji 'Ali's] representation on their behalf in the purchase, which is to be clarified in detail below, is based on the plenipotentiary authority given to him in this regard by the two of them personally and on their behalf in a court session, and Pavle also acting as the representative of his brother Antun who had authorised him, the Sharia validity of which has been established - made a purchase paid from the property of the two above mentioned

6 Which is how it reads in Siğill Mahkama al-Quds al-šar'iyya, No. 184, 35, line 3. The text of a writ kept

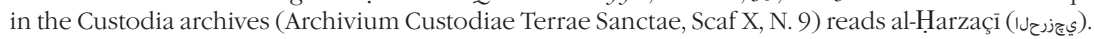


authorisers and their above mentioned brother Antun, in which no one else has any share and in which they have equal shares, from the pride of religious scholars, shaikh Șalähuddin, son of shaikh Ahmad al-'Alami, and from the esteemed shaikh 'Abdurrahmān, son of shaikh Ahmad al'Usayli, and from the first among the excellent shaikh Ahmad al-Šafi ' $i$, son of shaikh Sālih, and then from the pride of the peers ${ }^{7}$ Muhammad-bey, son of Aḥmad-bey Šamūm, and from Darvī̌ Ahmad Bayād, as well as from shaikh Ṣäliha, son of shaikh 'Alì al-'As 'ardī, from al-sayyid Ṣalāhuddīn, son of al-sayyid Șälih, from Mușihh, son of Muhammad al-Salvānì, and from Dayfullāh, son of Hamidullāh al-Salwānī.

The first seller is the above mentioned shaikh Șalāhsin son of al-'Alamī on the basis of an authorisation from the wife of his son, the pride of chaste women, Fädila-hätūn, daughter of late shaikh Muhammad al-Surūrì, whose representation on her behalf in the purchase to be clarified in detail below, at the price to be established, and representation in receiving the allocated amount is established on the grounds of an authorisation in this matter given verbally to him by her in the court session, which was communicated to her husband, the pride of orators shaikh Ahmad, as well as to her sister's husband shaikh 'Abdurrahmān al-'Usajli, and to the husband of her maternal aunt A ḥmad al-Šafi ${ }^{\top} i$, in the manner the Sharia basis of which is established.

The second seller is the above mentioned shaikh 'Abdurra mān al'Usayli, following a Sharia-verified authorisation given to him by his wife, the crown of rightly-guided women, 'Älima-hätūn, birth sister of the above mentioned Fädila-hätūn, whose representation on her behalf in the purchase to be clarified in detail below and acceptance of the price to be stated is in accordance with an authorisation given to him by her in the court session as well, which was communicated to the above mentioned shaikh Salāh, son of al-'Alamī, as well as the above mentioned husband of her maternal aunt, shaikh Ahmad al-Šăfi ${ }^{\prime} i$, in the manner that is adequate and in accordance with Sharia regulations.

The third seller is the above mentioned shaikh Ahmad al-Šafi ' $i$ on the basis of an authorisation by his wife, the pride of chaste women, Fahri-hatatun daughter of al-Hawāğ Muhammad, the crown of the community, whose

7 Fahr 'aqrānih.

8 Previously referred to as alā uddīn. 
representation on her behalf in all the above matters is in accordance with a verbal authorisation she gave to him in a court session, which was communicated to the above mentioned shaikh alä uddin al-Alami, as well as to the above mentioned shaikh 'Abdurrahmān al-'Usayli, in the manner the Sharia basis of which is established.

The fourth seller is the above mentioned Muhammad-bey, following a Sharia-verified authorisation given to him by his brother's daughter, the pride of chaste women, Mu 'azzama-hātūn, daughter of 'Ali-aga, where the authorisation relates to the purchase at a price to be stated, as well as to receiving the allocated amount and where it is, according to a Sharia-verified confirmation, considered a general authorisation, which also includes her guardianship over her son 'Abdurrahmān son of shaikh Muhammad al-Surüri, who is not capable of supporting himself, of dressing himself and meeting his basic needs, so that his share and interest are thus met, following a Sharia-verified permission.

The fifth seller is the above mentioned Darwiš, son of the above mentioned Ahmad Bayād, following a Sharia-verified authorisation given to him by Halima, daughter of Fahruddin, who is the wife of al-sayyid Isma' ill, son of al-sayyid Ğa far, whose authorisation on her behalf in the matter of purchase the price of which is to be established and stated, as well as the receiving of the allocated amount, is based on a Sharia-grounded testimony of al-sayyid Șalāhuddin son of Șalih and shaikh älih al-'As 'ardī, who know her as required by Sharia regulations, which is established in the manner prescribed by Sharia. The above is also related to the Sharia guardianship over Muhammad and $\underline{H}$ alill, sons of the above mentioned Isma 'ill, who are under age and incapable of taking care of their own dressing and livelihood, and who have their interest in this matter, ${ }^{9}$ for which there is a Sharia-verified permission.

The sixth seller is the above mentioned shaikh Șälih al-'As 'ardì, following a Sharia-verified authorisation given to him by al-sayyid Muhammad, son of al-sayyid Ğa'far, and by al-sayyid Bakrī, son of al-sayyid Salih, whose authorisation on their behalf for the purpose of the purchase, to be stated detailed below and at a price to be stated, as well as for the purpose of receiving an allocated amount, is based on the testimony of the above 
mentioned Darwī̌s, son of 'Aḥmad, and al-sayyid Șalahuddin, which is established according to Sharia.

The seventh seller is the above mentioned al-sayyid Șalähuddin, on the basis of an authorisation given by his wife Mu'ayyad-hätūn, daughter of al-sayyid Șälih, where an authorisation on her behalf in the matter of purchase to be detailed below, the price of which is to be established, as well as the receiving of the allocated amount, is based on a testimony of the above mentioned Darwī̌a, son of Ahmad, and shaikh Salih al- 'As 'ardi, who know her as required by Sharia regulations, which is established in the manner prescribed by Sharia.

The eighth and ninth sellers are the above mentioned Muṣlih, son of Muhammad, and son of his brother, the above mentioned Dayfulläh, personally and on his own behalf.

They [the sellers] sold personally and on their own behalf to him [the authorised purchaser], by means of authorisations and on the basis of the right of guardianship as stated above, after he [the authorised purchaser] was given a Sharia-verified permission by the authorisers, Pavle and Jakov and their brother Antun, where they enjoy equal shares, while the sellers have different shares among them. He [the authorised purchaser] purchased from them [the sellers] for his above mentioned two authorisers and their brother, the above mentioned Antun, by incontestable purchase that which belongs to those who have personally agreed to the purchase, to those who have agreed to the purchase by means of persons they duly authorised, and to those under someone else's guardianship, all of whom are mentioned above, so that what was in their legal possession and disposal became their [the purchasers'] ownership in a Sharia-adequate manner and they came to possess it without any rival having appeared prior to the conclusion of this purchase.

The purchase is related to the entire joint part, the surface of which amounts to eighteen qirats which, in proportion, account for three-quarters of the main part that amounts to twenty-four qirats ${ }^{10}$ of all the seedlings of fig and olive and other things planted in the garden, ${ }^{11}$ which remain subject to the decision according to which it belongs to the endowment

\footnotetext{
10 The usual way of counting parts when selling or inheriting. The property in question was divided into twenty-four equal parts (qirät).

11 Hākūra - orchard, garden.
} 
of the al-Salāhiyya madrasah, situated outside the Holy City of al-Quds, on the east side in the proximity of the grave of al-Sayyida Maryam, ${ }^{12}$ also including a cave and piles of stones, as well as a part running parallel with the above mentioned part, which is included in the above mentioned usable land property the co-owners of which are the above mentioned Muslih and the son of his brother Dayfullah, who own the remaining fourth. The plot of land where the above-mentioned seedlings are situated is enclosed by a vineyard owned by Șalähuddin and Mușlih, sons of Sälim; on the east side is a pedestrian path leading to the mount of Tiüri3; on the north side are olive seedlings owned by Franciscan friars permanently residing in the Holy City of Quds; on the west side is an access road, with all the entitlements related to this part, access routes and walls, goods and benefits it yields and all other things known as belonging to this plot of land and as associated to it, as well as with all the entitlements legally related to it in this regard.

The sale is unconditional and the purchase irrevocable and voluntary, without any uncertainty, conditionality, threat, violence or irregularity that may lead to deception, where they [the purchasers] are completely familiar with it [the subject of purchase] as required by Sharia regulations, leaving no room for ignorance, and where everything is in accordance with Sharia regulations, at the price of ninety groschen, to be divided immediately, as will be described in detail.

The part sold by shaikh Șalāh al- 'Alamī and shaikh 'Abdurrahmān al- 'Usajli, pursuant to an authorisation by their authorisers, the above mentioned Fädila-hātūn and 'Alima-hātūn, and by the above mentioned Muhammad-bey, pursuant to an authorisation of the above mentioned Mu'azzama-hätūn who, in turn, on the grounds of guardianship, represents the above-mentioned minor, 'Abdurrahmān, in the above-mentioned subject of sale amounts to three qirats, equalling fifteen groschen out of the defined price, pursuant to regulations of Sharia hereditary law.

The part sold by the above-mentioned shaikh Ahmad al-Šafi ' $i$, as authorised by the above-mentioned Fahri-hätūn, amounts to three qirats out of the defined subject of sale, also equalling fifteen groschen.

\footnotetext{
12 Maryam, Virgin Mary.

13 The Mount of Olives.
} 
The part sold by the above-mentioned Darwiš out of the defined subject of sale, as authorised by the above-mentioned Halima-hätün who, in turn, on the grounds of guardianship, represents her minor sons Mu ammad and Halil, amounts to two qirats, equalling ten groschen out of the defined price, to be divided among them according to regulations of Sharia hereditary law.

The part sold by the above-mentioned shaikh äli al-'As 'ardī, as authorised by the above-mentioned al-sayyid Muhammad and al-sayyid Bakrīj, amounts to two qirats out of the defined subject to sales, as the part belonging to the above mentioned al-sayyid Muhammada, equalling ten groschen out of the price, and one qirat and one-third belonging to the above mentioned al-Bakri, equalling one and one-third groschen out of the price.

The part sold by the above-mentioned al-sayyid Salähuddin of the defined subject of sale, as authorised by the above-mentioned Mu'ajjada-hattūn, amounts to two-thirds of a qirat, equalling three groschen and one-third out of the defined price.

The part sold by the above-mentioned Muṣlih and Dayfullah on their own behalf, with equal ownership in the part belonging to them, amounts to six qirats out of the above-mentioned subject of sales, equalling thirty groschen of the above-mentioned price.

The above mentioned sellers: those participating in the sale personally, those participating in the sale by means of an authorisation and those participating in the sale by means of representation in the capacity of guardians, as stated above, have received from the above purchaser, or from his above-mentioned authorisers, the entire recorded amount and divided it as exposed above, taking it from hand to hand, with the presence and witnessing, which is a manner of handing over that is in accordance with Sharia rules, which confirms that the above-mentioned purchaser and his above-mentioned purchasers do not owe anything from the defined price or any of its parts, and which also confirms that the defined amount of money is received in a proper manner according to Sharia and that an unconditioned purchase has been carried out among them by means of offering and accepting, handing over and taking over in a legitimate manner, following an inspection, introduction and reaching agreement according to Sharia regulations, and after a physical separation to the satisfaction of all the parties. 
As this [purchase] included a pledge ${ }^{14}$ and insurance from consequences, ${ }^{15}$ it is the sellers' duty to offer a guarantee immediately ${ }^{16}$ as required by Sharia regulations, which was duly performed after a group of Muslims stated that selling the part belonging to persons uncapable of managing the property represented was of benefit and use for these persons, since keeping the above-mentioned part, with it being small and not yielding any income, would not be beneficial for them. This statement was made in accordance with Sharia regulations, the content of which they unanimously confirmed before our esteemed, the above-mentioned Sharia judge, as required by Sharia regulations.

After this was announced and verified following Sharia regulations, the above mentioned brothers Pavle and Jakov requested it to be testified that, on their own behalf and, by means of an authorisation, on behalf of their above-mentioned brother Antun, they endowed and exempted, in person and by authorisation, as mentioned above, the property in their own possession, with their shares in it being equal, amounting to the entire above-mentioned subject of purchase clearly described above, in a manner representing valid endowment according to Sharia and indisputable exemption of property in accordance with Sharia regulations, therefore [they requested for it to be testified] that they endowed this waqf in favour of Franciscan friars residing in the al- 'Amüd monastery in the Holy City of al-Quds, and the Christian poor asking assistance from them. They then handed this over to the authorised representative of the above-mentioned Franciscan friars and their interpreters, having relinquished their ownership of it on their own behalf and on behalf of their above-mentioned brother Antun and having handed it over to the above-mentioned waqf. ${ }^{17}$ The handover on this occasion was performed in a proper manner according to Sharia regulations, the content of which was unanimously confirmed before our esteemed, the above-mentioned Sharia judge, as required by Sharia regulations, who made a Sharia-valid judgement accordingly, pursuant to the opinion of great scholars holding the described manner

14 Al-darak - pledge that the purchase takes from the seller as a guarantee in case a third party should claim the subject of purchase.

15 Al-tabi'a - responsibility for consequences.

16 Al-dimãn - the seller's guarantee against infringing the right to the subject of purchase by a third party.

17 The original uses the term al-waqf, also indicating endowment of property by non-Muslims. 
of waqfing valid, after a complaint was lodged ${ }^{18}$ in accordance with Sharia regulations in this regard, and after the complaint was responded to with a confirmation that the act was valid pursuant to Sharia law.

On the thirteenth day of the month rabi' al-tanni, in the year one thousand ninety-nine. ${ }^{19}$

Scribe [name illegible]

Witnesses present:

humble Zakariyyā al-Dīrī, humble Nașruddīn al-Šafi 'i, humble Mūsā, humble Muhammad Șun 'ullāh al-Hālidī, humble Mạ̣mud al-Halidī, humble Faḍlullāh al-Dağğānī, humble 'Abdurrahmān, the pride of peers Su' 'ud Džalabì al-Turdžamān, 'Alī Ibn Hasan al-Tarzī, humble Aḥmad al-

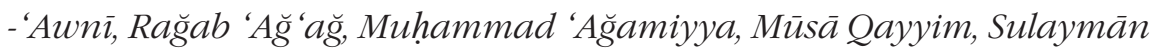
'Ağamiyya, Muḥammad al-Turkamān, 'Awda Halīlì, Hasan Sāhilì, Fāris Ibn Dāwūd, al-sayyid Fahruddīn Šitawī, al-sayyid Badruddīn Šitawì, 'Alī Qindilğ̄i, 'Abdulkarīm Qindilğĭ.20

\section{Does the subject of the contract include the Grotto of Gethsemane as well?}

When discussing the location of the garden of Gethsemane, Arce, probably misreading the document, makes a mistake. He says that »the garden boundaries reach the cave [...] The owners of this cave are Muslih and his nephew/brother's son Dayfullah [.] « He further says that »the Cave - belonging to Muslih and Dayfullah - was excluded from the contract«. (Arce 1971, 11) The cave that the text of the contract refers to was not excluded from the contract. The text, in fact, underlines that the garden also includes a cave (al-muštamala 'alā mà்àra). ${ }^{21}$ Furthermore, it is not possible to conclude from the very document that the cave owners were Muslih and

\footnotetext{
18 This refers to customary fictitious court proceedings, usual in such cases, initiated so as to confirm the irrevocability of waqfing (endowment of property).

19 Corresponding to May $2^{\text {nd }} 1681$.

20 Archivium Custodiae Terrae Sanctae, Jerusalem, Scaf X, N. 9.

21 Line 23 in the text of the document ( $h u g \breve{g} \breve{g} a$ ), Archivium Custodiae Terrae Sanctae, Jerusalem, Scaf X, N. 9 .
} 
Dayfullah. After all, if they were the cave owners and if the cave had been excluded from the purchase contract, how could they appear in the contract as sellers who received 30 groschen? The cave and stone piles were more likely deliberately cited as part of the subject of purchase in order to prevent a possible opposite conclusion. Namely, the subject of waqf or even the disposal of waqf in terms of al-hikr implies something that produces benefit (seedlings, houses, etc.) and, since the cave and stone piles do not belong among things that produce benefit in this sense, it is then underlined that they also belong to the purchased plot of land.

\subsection{The object of the sale}

It is well known that regulations on waqf do not allow replacement or sale of waqf property, except in a case of a necessary or more adequate replacement. Even in such cases, the sale is performed by the mutevelli (al-mutawallī) or nazir (al-nāzir) of the waqf. This document does not state that the waqf property is to be replaced; in addition, the sellers are individuals, not the waqf nazir or mutevelli. This raises the following question: How could something belonging to a waqf be sold before the Sharia court in Jerusalem, or what kind of sale is it? To answer the question, it is important to look closely at a provision in the document stating that the subject of sale are "all the seedlings of fig and olive and other things planted in the garden (al-häküra), which remain subject to the decision according to which it belongs to the endowment of the al- alāhiyya madrasah" (min gamī' garās al-tīn wa al-zaytūn wa gayrih al-qā' 'im 'ușüluh bi al-ḥākūra al-ğārì qarāruhā fì waqf al-madrasa al-Salāhiyya). ${ }^{22}$ This begs another question: how could the orchards planted on the land belonging to the waqf be sold as private property, with the land itself or the garden (al-hāküra) remaining in the ownership of the waqf of the al-Ṣalāhiyya madrasah? It is quite certain that the waqf land was treated in the spirit of al-hikr. ${ }^{23}$ Pursuant to al-hikr regulations, land belonging to the waqf may

22 Line 23 in the text of the document ( $h u \underline{g} g \breve{g} a$ ), Archivium Custodiae Terrae Sanctae, Jerusalem, Scaf X, N. 9. Arce does not pay any particular attention to this provision and his translation of it is somewhat arbitrary: "Y como dicho huerto pertenecia desde antiguo a la Salā iyya o iglesia de Santa Ana, asi quedará para siempre." (And since the garden has for ages belonged to Salahijja or the Church of Saint Anne, thus it shall remain forevermore.) (Arce 1971,9)

23 This form of managing waqf property turned out to be detrimental for the waqf property itself. Leasing out waqf property for building or planting fruits or similar things eventually turned into 
be leased out for a long period for building and planting crops or fruits, where an agreement is made for a substantial amount of money to be paid at the very beginning and for smaller amounts of lease to be paid annually. Furthermore, the period for which the land is leased out has to be agreed on as well. Some believe that the period and the use of waqf land for building and planting do not have to be defined and can, rather, be unlimited. ${ }^{24}$

This way of managing waqf property in the end turned out to be detrimental for waqf and often represented misappropriation of waqf property. In the case of purchasing the Gethsemane garden, there is no mention of the period for which the waqf property was given out in the spirit of al-hikr, which, taking into account the position of the most permissive legal experts, could even be acceptable. It could be that this issue was regulated by another document or that it was some sort of »legal resourcefulness" which did not make the sale of waqf property apparently definitive, as the garden itself remained de jure in the ownership of the waqf of madrasah al-Ṣalāhiyya, while the orchards planted in it were sold to other persons who, in turn, bequeathed them for different purposes. Records of the Sharia court in Jerusalem list the cases of managing the property of madrasah al-alāhiyya in terms of al-hikr. Land belonging to the waqf of this madrasah was leased out for the purpose of planting fruits or for construction where, at the same time, the beneficiary of such right could sell his lease, or »benefit« (manäfi ${ }^{\circ}$, to another person. ${ }^{25}$

We could not find any other sources or literature in Arabic, apart from the document in question, that pay attention to the purchase of the Gethsemane garden by the Branković brothers or even mention it or the

possessing the same land. How close long-term lease was to a factual sale of property can best be testified to by the fact that a part of Gethsemane land ('aräḍi al-Gismäniyya) from the waqf of madrasah al-Ṣalā iyya was leased out to the Jewish community as a graveyard (see Rabāya'a 2008, 112). In the year $967 \mathrm{AH}$, before the Sharia court in Jerusalem, a contract was made on the price of leasing out the Gethsemane land ('arā 1 al- ismāniyya) for »burying Jews who lived in Jerusalem«, defining that the amount of lease was one hundred Cypriot gold dinars for "every Arabic lunar year" (li kull sana hilāliyya 'arabiyya). (Siğill, No. 39, 319-320; al- 'Asalī 1985, T. 1, 294-295)

24 On al-ikr see Šafīq Bāšā 1344 AH.

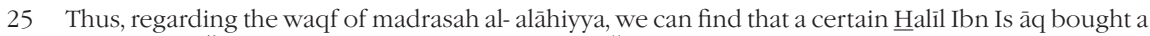
garden from Šamsuddīn Muammad, son of shaikh Ğalāluddīn, in which grapes and figs were planted. (Siğill Maḥkama al-Quds al-šar’iyya No. 1 [3], 936 AH/1530, 43) 
disagreement it caused on the part of authorities or Jerusalem dignitaries. The reason behind it can be that the sale of seedlings and other things in terms of al-hikr was considered quite common, where Muslims themselves did not regard this place as one of their holy ones. Furthermore, the buyers were Ottoman subjects and could, as such, much easier have been in a position to legally perform the purchase. It is not insignificant that they came to Jerusalem in the accompaniment of representatives of Bosnian Franciscan friars, who represented the »local church institution « because »in the heart of the Turkish Balkans, in the territory between Belgrade and Istanbul, the Franciscan Province of Bosna Argentina was the only Catholic institution tolerated by Turkish authorities«(Tóth 2002, 181).

\subsection{The buyers, the Branković (Brajković) brothers}

Brothers Pavle, Jakov and Antun from Sarajevo, as the buyers of the Gethsemane garden, are usually mentioned under the family name of Branković. It is evident from some sources, as we will see below, that they actually posed as the Branković family, while their original family name was Brajković. Introducing themselves under the name of Branković, they wanted to show that they belonged to the old noble Branković lineage, aspiring to receive from Vienna the title of nobility of the old Branković family, together with all the privileges related to such a title (Lujić 211, 5). The purchase of the Gethsemane garden, where they introduced themselves under the name Branković, and the confirmation they were issued by a general of the Franciscan order, enabled them to document and authenticise the family name of Branković, and to get a credible document in this regard (Fermendžin 1892, 517). Going under the name of Branković, they would, by historic coincidence, at a later stage find themselves in the Balkans and Austria in a role they had never even dreamed of.

According to one of the interpretations, the Branković brothers came to Jerusalem as pilgrims to the Holy Sepulchre and that the Custos of the Custody of the Holy Land, Fr. Sormanus, made them knights of the Holy Sepulchre and they then purchased the Gethsemane garden out of gratitude (Klaić 1914, 73). The Register of the knights of the Holy Sepulchre reads that, on $4^{\text {th }}$ April 1681, Generosus Dns Paulus Augustini Brancouich Saraibia ex Bosna Arg.na and Generosus Dns Iacobus Augustini Brancouich Saraibia ex Bosna Argentina were made the knights of the 
Holy Sepulchre and that, on $10^{\text {th }}$ May of the same year, the same title was bestowed on Nobilis Dominus Antonius Augustini Brancouich Saraibia ex Bosna Argentina, as represented by his older brother Pavle. ${ }^{26}$ Pavle and Jakov, the two brothers who were present at the purchase, received their knighthood of the Holy Sepulchre before they purchased the garden and endowed it, while Antun, who did not come with them to Jerusalem, was granted the same title, as represented by his brother Pavle, after the purchase.

Fra Mihajlo Radnić (Fra Mihaylo Radnich Baçanin ${ }^{27}$ refers to brothers Pavle, Jakov and Antun as Brajković. While he was the custodian of the Province of Bosna Argentina, Radnić published a book entitled Pogargegne izpraznosti od sviyeta [Denunciation of the Vanity of the World] in Rome in 1683. At the beginning of the book, the cover page of which says "Sloxeno i izuageno u Iezik Slouinsky Bosansky « [Compiled and made in the Slavic Bosnian language], he wrote an inscription to the three brothers: "To my most exalted and illustrious gentlemen, Pavle, Antun and Jakov Brajković, Augustinović, birth brothers from Sarajevo, Bosnia noblemen and knights of the honourable sepulchre of Jesus Christ of Jerusalem D.D." (PRIVZVISCENOY, I PRISVITLOY MOIOY GOSPODI PAVLV, ANTVNV, IAKOVV, BRAYKOVICHEM, AGVSTYNOVICHEM, BRATHI ROGENOY, SARAYLIAMI, PLEMICHEM BOSANSKYEM I VITEZOVOM SLAVNOGA GROBA ISSVKARSTOVA OD IERVZOLIMA. D. D.) (Radnich Baçanin $1683,2)$

That the brothers' family name was not Branković can be testified to by a fact relating to the relationship between Ritter Vitezović (1652-1713) and the Branković brothers. Namely, Vitezović was rather helpful to the Branković brothers when they came to Vienna in 1688. They aspired

26 (Picirillo 2006, 135.137) (I obtained the facsimiles of this phototype edition by courtesy of Fanika Krajnc-Vrečko, PhD, head of the Theological Library in Maribor, and professor Nedžad Grabus, PhD, Ljubljana Mufti).

27 About fra Mihajlo Radnić see: Vasiljev (1940, 1-14); Sekulić (199, 37-38); Božitković (1935, 100-105). His name is often written as Mihovil, iven in Hrvatski franjevački biografski leksikon, there are two entries about fra Radnić, one after another, with the same data: RADNIĆ (BAĆANIN, UZUM), Mihovil, provincijal (Kaloča, 1636-Budim, 26.IX.1707) i RADNIĆ, Mihajlo, provincijal, pisac (Kaloča, 1636. Budim, 26.IX.1707). See: 2010. Hrvatski franjevački biografski leksikon. Franjo Emanuel Hoško, Pejo Ćošković, Vicko Kapitanović, eds. Zagreb: Leksikografski zavod Miroslav Krleža, Vijeće franjevačkih zajednica Hrvatske i Bosne i Hercegovine, 591-592. 
to obtain the Branković title of nobility and Vitezović, being someone who studied genealogy and heraldry of noble families, helped them. However, their relationship went wrong when Pavle, the eldest of the Branković brothers, did not give his consent to Vitezović to marry his daughter Marija. In the beginning they explained that she was too young but it turned out they were not willing to give her hand to Vitezović because he was just a plain nobleman. Thus in 1694, six years after the Branković brothers were granted the right to use the title of count, Ivan - Pavle's son - wrote a lengthy letter to the bishop of Zagreb, Selišević, explaining that Vitezović »initially approved without any objection and obliged himself to work through the documentation about their lineage they gave him to read; and now, when they refuse to give him Marija's hand in marriage, he calumniated them saying that they shrouded themselves in a false name and took the credit for Christianity that was not theirs to take« (Klaić 1914, 91). In order to support the claim that his family was indeed the Brankovic family, Ivan Branković says in the same letter that »during Turkish rule, in order to conceal their origin and avoid Turkish persecution, they used patronymic surnames, especially his father and uncles took the paternal name of Augustinović (Augustinovich paterno nomine) after their grandfather Augustin but they always knew that they were of the Branković lineage« (Klaić 1914, 91-92).

\subsection{The Branković brothers vs Count Đorđe Branković}

There was another Branković who, at around the same time as the Brajković/Branković brothers, presented himself as a descendant of the medieval nobility family of Branković. It was Đorđe Branković (16451711), of a distinguished Orthodox family from Ineau in Arad County, who represented the ruler of Transylvania at the Ottoman Porte. In 1673, he secretly delivered a submission to the Austrian emperor in which he rather ambitiously stated that, at a convenient moment, he could lead Serbs, or even other Christians, as well, to subjugate Hungarian insubordinates and form some sort of an Austrian military borderland towards Turkish territories. (Radonić 1911, 180-185)

Since during the Great Turkish War Austria welcomed any assistance, Leopold I bestowed on Đorđe Branković the title of baron in 1683 and, on $20^{\text {th }}$ September 1688, the title of count as well. Đorđe 
Branković's ambitions and plans were quite unrealistic. In addition to requesting that a number of estates in southern Hungary be restituted to him as an heir to Despot Branković (Radonić 1911, 334), he also presented plans according to which he would be the ruler of a great Illyrian state to be established in the Balkans. Moreover, he participated in the negotiations between Wallachia and Russia. After his ambitions began to disrupt the Austrian plans in the Balkans, Leopold I summoned him to Vienna in 1689 and put him under house arrest, where he remained until his death.

The Bosnian Brankovićs were not as ambitious as Đorđe Branković. Still, according to Jablanović, they felt the time was right for them to capitalise on their reputation and request their right to a title of nobility. It was the time following the Turkish defeat at Vienna, the fall of Buda, Turkish defeat at Mohács, in Baranya, Bačka, Slavonia and elsewhere, when it seemed that the Turks would soon be defeated in the Balkans as well $(1931,66)$.

The Bosnian Brankovićs appeared at a perfect moment for Vienna. On the one hand, Leopold I welcomed their appearance as an argument proving that unreliable Đorđe Branković was a false pretender to a title of nobility and, at the same time, the Emperor used the Bosnian Brankovićs, primarily Pavle Branković, as those who could use their despotic family name to replace unreliable Đorđe Branković in the Balkans. (Radonić 1939, 518-519)

Did Leopold I really count on the Bosnian Brankovićs as someone who could at a certain moment be accepted by the Serbs and substitute Đorđe Branković as heirs to Despot Branković? According to Taloci, this was Vienna's intention precisely: »to unmask the other Branković and to inform the Serbs, they sent the eldest brother, Pavle, to the Kladovo camp of Louis of Baden-Baden, with a warm recommendation " $(1899,80-81)$. On $29^{\text {th }}$ October 1689, count Đorđe Branković was arrested in the Kladovo camp of the Prince of Baden-Baden, from where he was escorted to detention in Vienna (Radonić 1939, 395-396). In this regard, Leopold I conferred a diploma for merits on the Branković family, Pavle and his brothers Jakov and Antun and their sons Ivan, August and Franjo, with guarantees that, following the conquest of Bosnia, they would be granted their positions and estates, which is very indicative. Immediately after this, the diploma reads that the Serb Patriarch was free to control all eastern churches of Greek rite, to anoint episcopes, deploy priests to monasteries, to build 
churches by virtue of his power where necessary, to position priests: in short, to exert church power across Greece, Rascia, Bulgaria, Dalmatia, Bosnia, Ineu and Herzegovina, as well as in Hungary and Croatia, where they can be found. ${ }^{28}$

The content of this diploma is somewhat odd, as it consists of an acknowledgement and guarantees to the Bosnian Branković family, and of guarantees given to the Serb Patriarch regarding his powers. The focus here is on the guarantee of the Serb Patriarch's jurisdiction in Hungary and Croatia. A possible interpretation of such contents of the diploma could be that there was an attempt to portray the Bosnian Brankovićs as protectors or guardians of Serb interests, as intermediaries instrumental in spreading the church power of the Serb Patriarch in Hungary and Croatia, at the cost of complete suppression of, by now only symbolic, presence of count Đorđe Branković.

In a study related to the church union at the Croatian military border, drawing attention to this diploma, Schwicker says the following: „Emperor Leopold wanted to use the protection he was to offer to Serbs as a pledge of Serbian loyalty to the imperial cause so, on $21^{\text {st }}$ August 1690, he issued an official privilege approving the requests made on $18^{\text {th }}$ June, with these guarantees being reemphasised two days later in an acknowledgement to Serb notables Pavle, Antun and Jakov Branković« (Schwicker 1875, 283-284). It is interesting that Schwicker refers to the Branković brothers as Serb notables (die serbichen Notabeln).

The authorities in Vienna still worked on discrediting Đorđe Branković as a false pretender, using the Bosnian Brankovićs for this purpose. For instance, in a deed ${ }^{29}$ that Leopold I gave to Augustin Branković (a son of one of the buyers of the Gethsemane garden) on 18 December 1703, confirming that the Bosnian Brankovićs were heirs to the despotic lineage, Đorđe Branković is called a schismatic, renegade from the Catholic Church (schismaticum, et ab ecclesia Catolica alienum) and "a fictitious Branković»

\footnotetext{
28 Czoernig 1875, 93-94.

29 Vitković $1875,194-198$.
}

Edinost in dialog 74 (2019) 2: 61-86 
(fictitium Brancovich)..$^{30}$ The first of these two designations of "Orthodox" Branković evidently comes from the "Uniate Church discourse.$^{31}$

The absence of Đorđe Brankovićs political power was now, on the Serb part, compensated by a symbolical power arising from his invoking the background of the old despotic lineage. Thus, a letter that the Pakrac Orthodox bishop, Sovronije Podgoričanin, wrote to despot Đorđe Branković on $6^{\text {th }}$ December 1704, says that a self-proclaimed and false Branković - most likely referring to Augustin - used political flattery "to win our help for his intentions « and that he sent to the Emperor »a memorial worthy of his imperial highness« expressing his loyalty to one despot alone.

Considering all mentioned data relating to the strife of the Bosnian Brankovićs, on the one hand, and that of Serbian Đorđe Branković on the other, to prove they were heirs to the despotic Branković lineage, as well as all the disputes that included their personal participation or that of various other elements, and considering that the context they found themselves in was rather serious, the following data can justly be called historiographic irony. Namely, the Bojničić list of Croat and Slavonian noblemen reads that, on $23^{\text {rd }}$ October 1688, Emperor Leopold I conferred the title of count on "Đorđe Branković and his sons Pavle, Anton and Jakov" ("Grafestand [...] für Georg Brankovich u. für seine Söhne Paul, Anton u. Jakob«) (Bojničić $1899,21)^{32}$

\footnotetext{
30 Vitković 1875, 194-195.197-198.

31 Vitković 1875, XVI; Kudelić 2010, 137-138 ff. 7, 166-167.

32 Bojničić 1899, 21.
} 


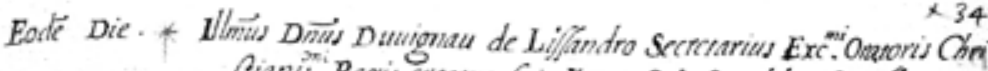
frianis. Regis cratus fuit Eques S habitï Eque Pris Milurie in abs." R P.F. Francifro Courcois

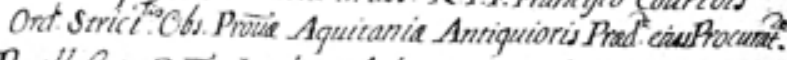

Die 12.gtris * Perillyfris Dnus Iacobus Auber Turonenfis, criarus fuir Eques Snit Scpulchri fufeipt: pro co habirum Equefris Milinia in ajentia R.P.F Saluat' Ferran Proüs Catalonia Predicusor

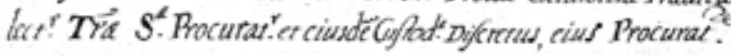

. All10 D

Die io. Fetr * Illmus er Excomu D D. Comés Petrus de Almedia ProRex Lusitanus Indiar? Oriontalium, creatus fuit Eques S Bniscoutchri

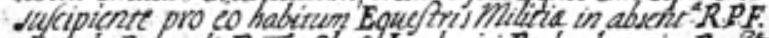
Angelo Berardi Prowe abs. S. Lituduici Prad aclect. cius Proc.

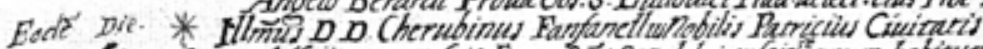

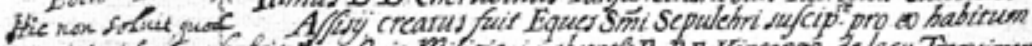

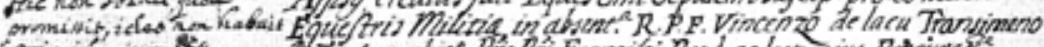

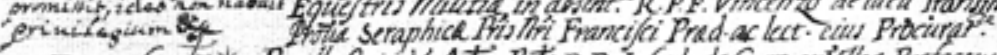

Die 26. Jor * Perillyfris 26 Adm RAt D.D.Ioleph de Cerro er VIlon Pnefecrus Gubi: culi Illmir R mi v. D. Archiepisconi Angzli Crutitatis Calaris in

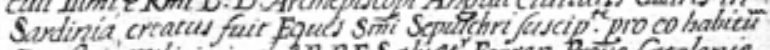

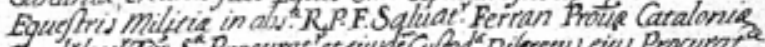

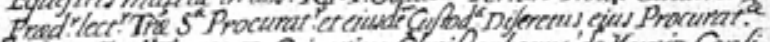

Eodé Die. * Il mus er Excltmus D.D.Giongius Chrifophorus de Kuniz. Confi-

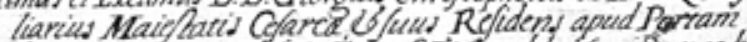

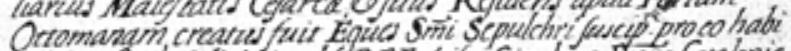

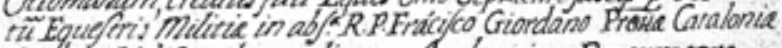
Predicat? 26 Pamchus in lingua Araba, cius Procumatore.

\section{Anno $D \overrightarrow{n i} M D C L X \times X I$.}

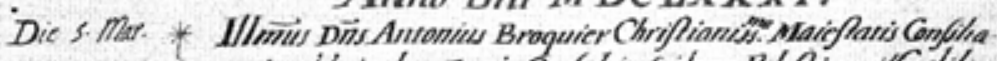

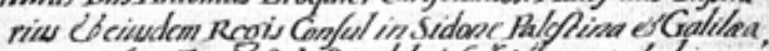

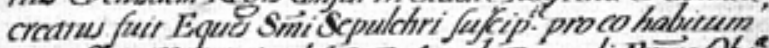

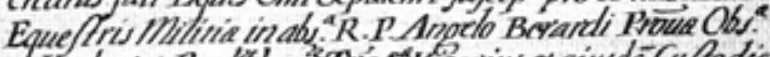

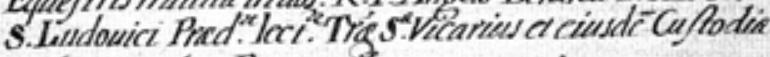
Difrerus, cius Procurat

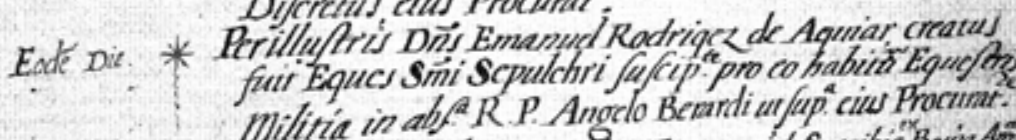
Milifía in abf R P. Angelo Beardi urfup cius Procunat.

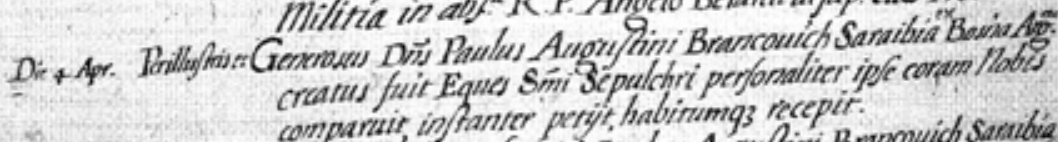
companut, inf ranter perzit, habinumgs recepit.

Eodŕ Die

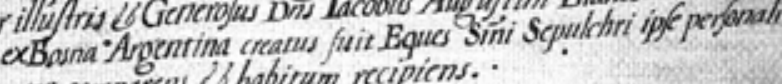
er comparens 2 habirym recipiens. .

The Register of the knights of the Holy Sepulchre reads that, on $4^{\text {th }}$ April 1681, Pavle Branković (Paulus Brancouich) and Jakov Branković (Iacobus Brancouich) were made the knights of the Holy Sepulchre. (Picirillo 2006, 135) 


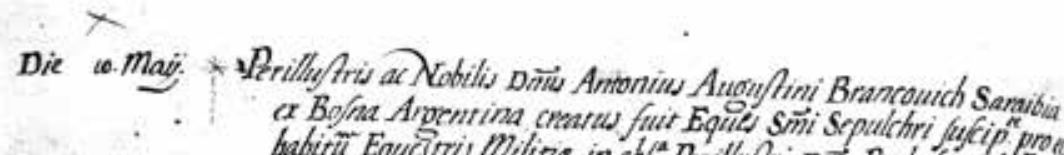

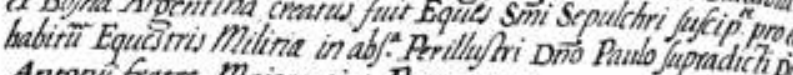
Dic 27.May. * I/mus Drus nobilis Copitancus Hicrony Ciss Dnus hobilis Capitancus Hicronymus Maria Abdua

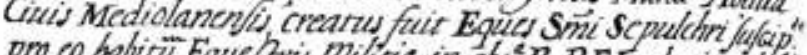

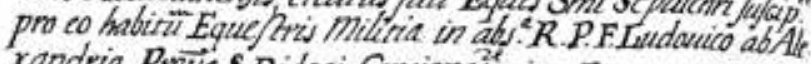

Dic 20.Aug. * Xandria Prous s.Didaci Concionat: cius Procumeore. -

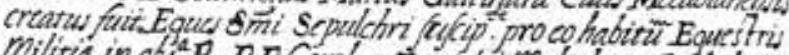
miliria in abs. R. P. F Carolu Frin a Medidano Predrelect" The s. decretarius eius Procurate

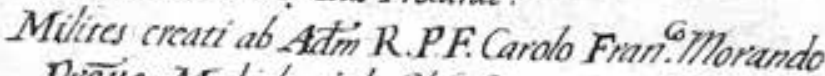

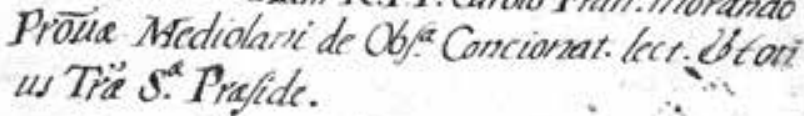

AnIODNIM DCLXXXII.

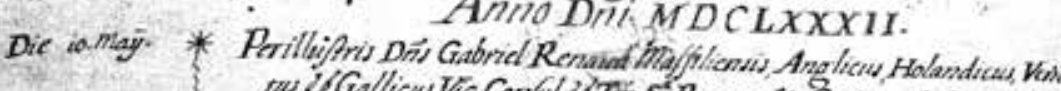

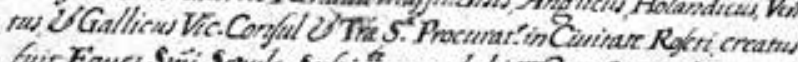

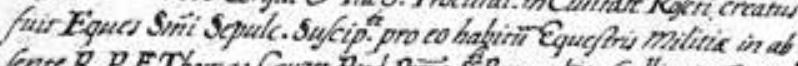

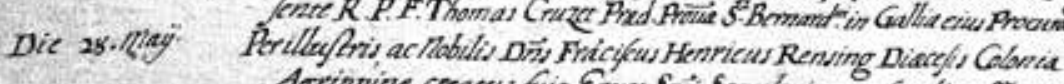

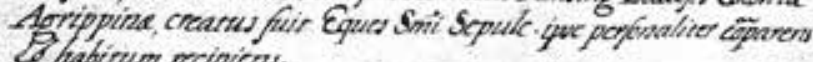

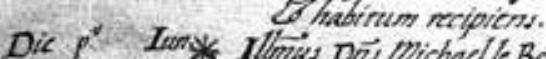

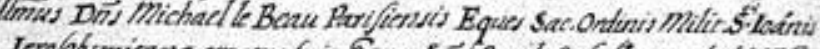

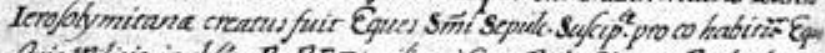

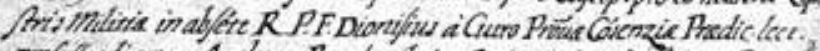

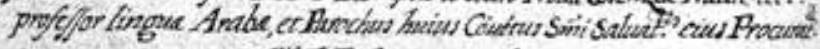

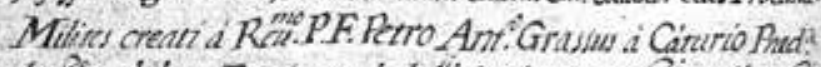

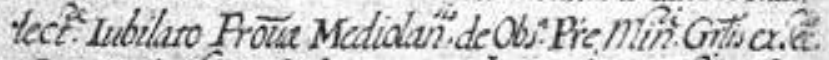

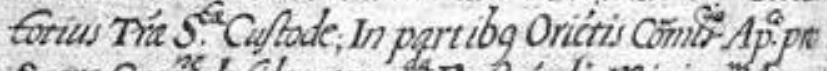

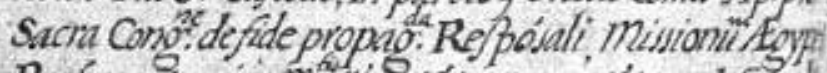

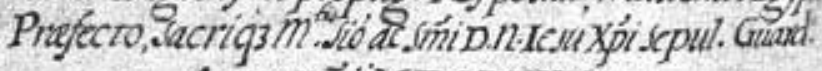
Anno DñiMDCLXXXII.

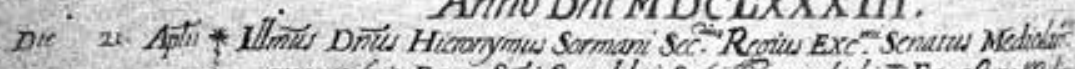

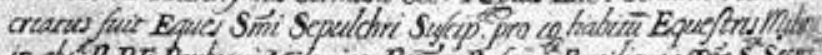

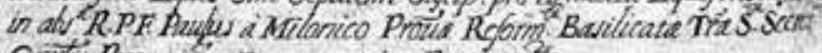
Gintis Puconis c Decanus cius Procura?

The Register of the knights of the Holy Sepulchre reads that, on $10^{\text {th }}$ May 1681, Antun Branković (Antonius Brancouich) was made the knight of the Holy sepulchre. (Picirillo 2006, 137) 


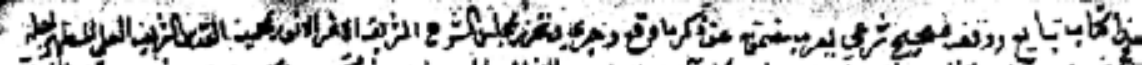

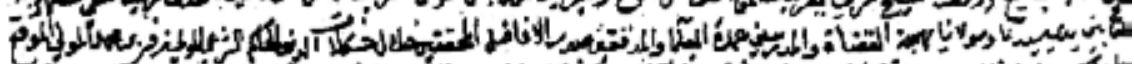

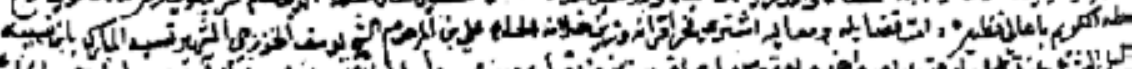

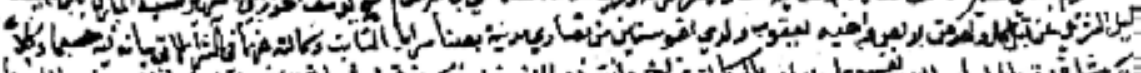

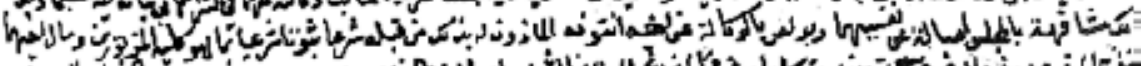
-

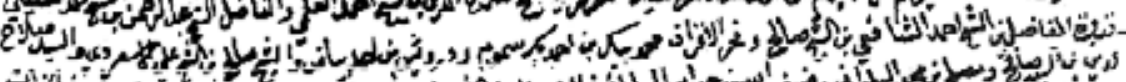
is

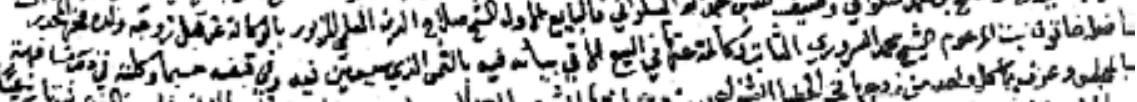

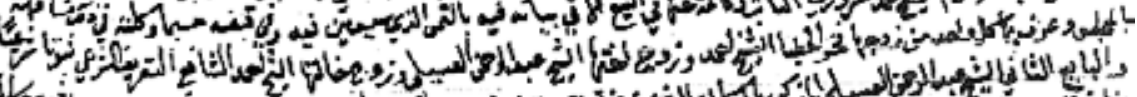

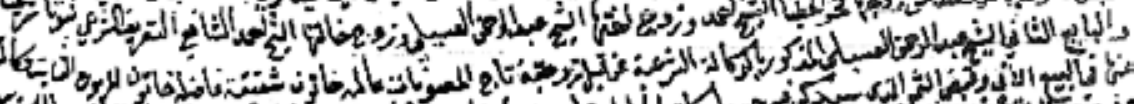
.

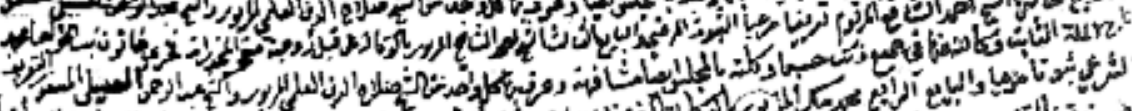

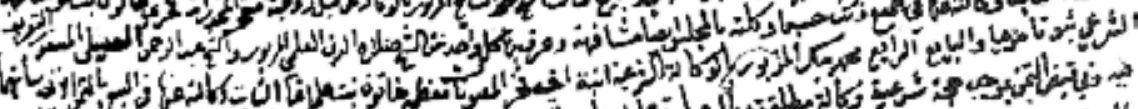

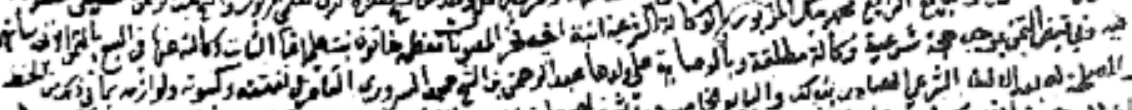
. ج"

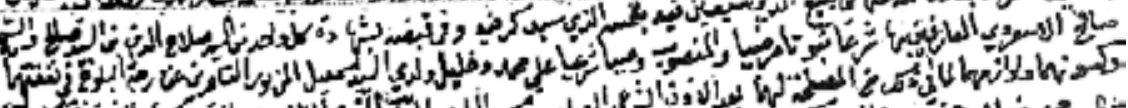

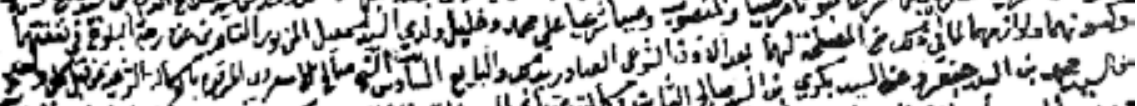
-

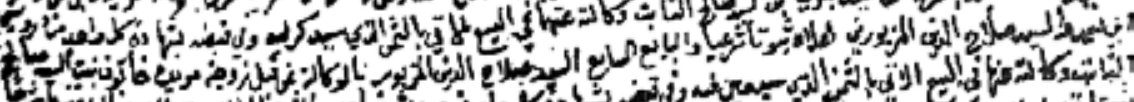

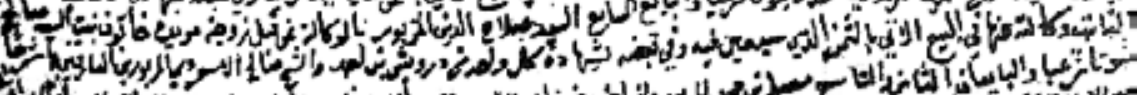

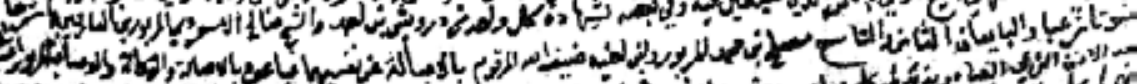

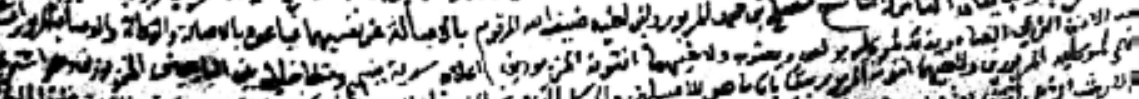

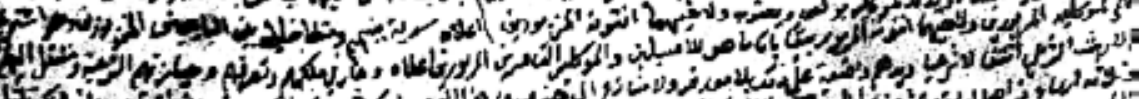

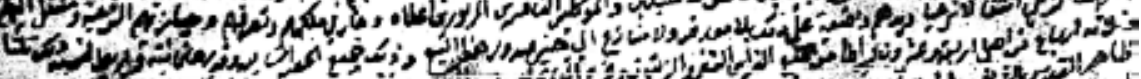

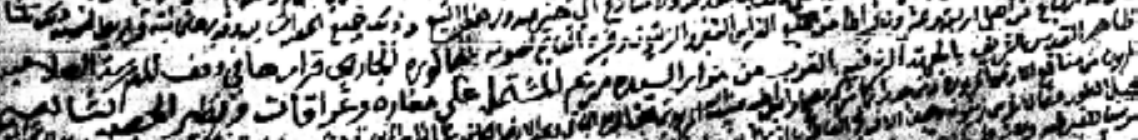

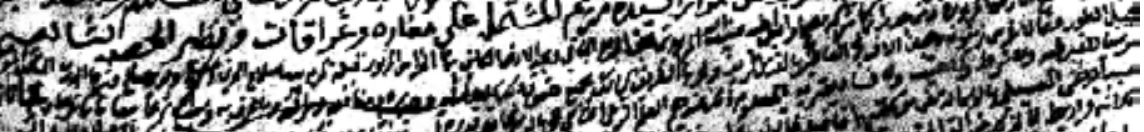
os J

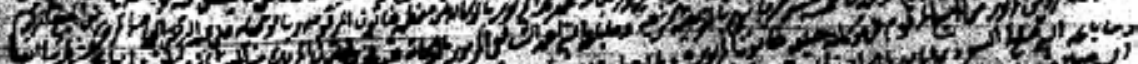

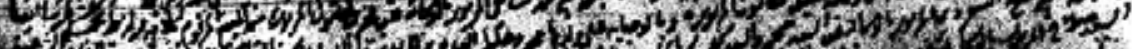
Q6

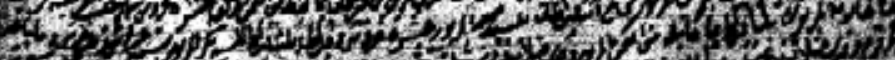
3. 


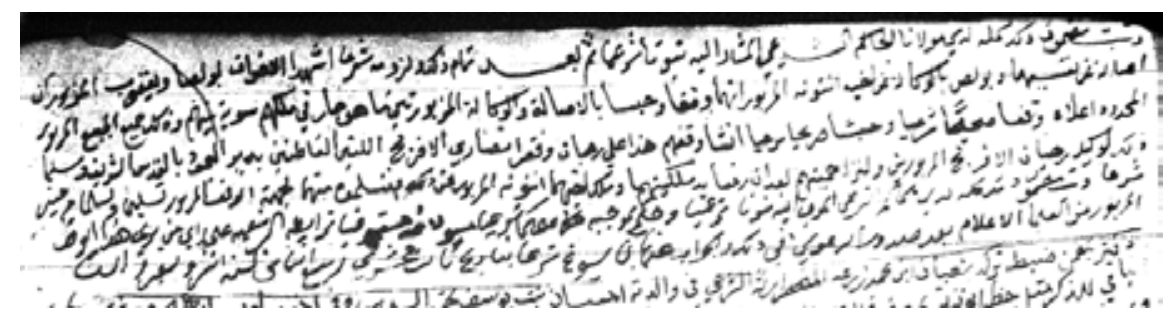

The Document on purchase and endowment of the Gethsemane Garden (Siğill Mahkama al-Quds al-šar'iyya (Jerusalem Sharia Court Record), No. 184, 1092, h/1681, 35-36) 


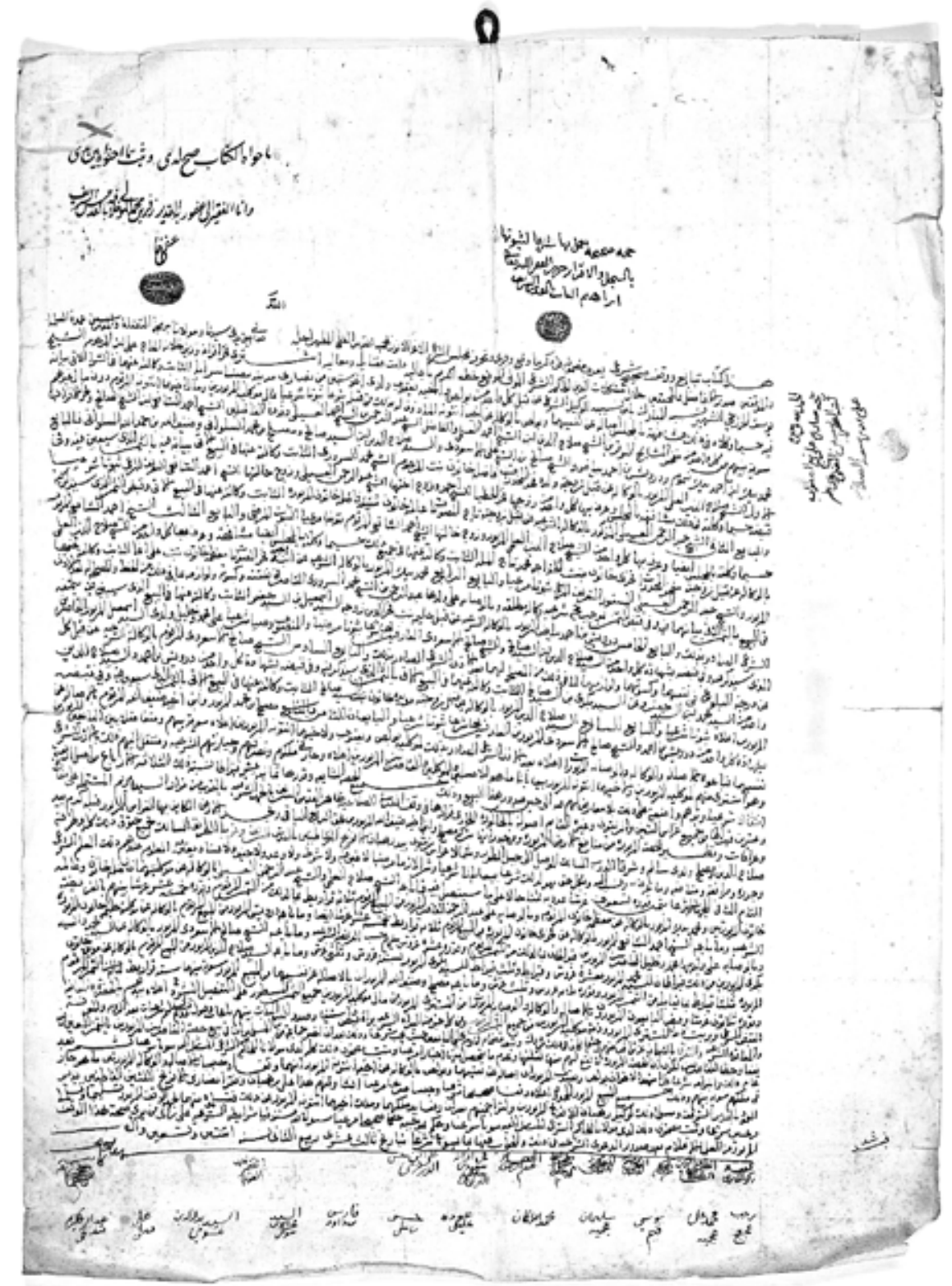

The Document on purchase and endowment of the Gethsemane Garden (Archivium Custodiae Terrae Sanctae, Jerusalem, Scaf X. N. 9) 


\section{References}

A mad, Ruwayda Fa 1 Ahmad. 2015. al-Madrasa al-alà iyya fì al-Quds (336-588 AH) 1192-1918), an unpublished Master's thesis defended at the al-Nağa State University in al-Nābulus.

Arce, Agustín. 1971. Getsemani; adquisición documentada del Huerto de los Olivos, de la Gruta de Getsemaní, de varios Olivares. Jerusalem: Franciscan Printing Press.

Archivium Custodiae Terrae Sanctae. Jerusalem, Scaf X. N. 9.

'Asalì (al), Kāmil Ğamīl. 1985. Wa ā'iq maqdisiyya tārīhiyya. 'Ammān: Mu'assasa 'Abdul amīe Šūmān.

Boas, Adrian J. 2001. Jerusalem in the Time of the Crusades: Society, Landscape and Art in the Holy City under Frankish Rule. London and New York: Routledge. Https://doi. org/10.4324/978020399 6676.

Bojničić, Ivan. 1899. Der Adel von Kroatien und Slavonien (edition J. Siebmacher's grosses und allgemeines Wappenbuch, IV. 13). Nürnberg: Verlag von Bauer und Raspe.

Božitković, Juraj. 1935. Kritički ispit popisa bosanskih vikara i provincijala (13391735). Beograd: Štamparija Dragomira Popovića.

Czoernig, Karl Freiherrn v. 1875. Ethnographie der Oesterreichischen monarchie, 3. Band, Wien.

Fermendžin, P. Eusebius. 1892. Acta Bosnae potissimum ecclesiastica cum insertis editorum documentorum regestis ab anno 925 usque ad annum 1752 , Monumenta spectantia historiam Slavorum meridionalium, V. 23. Zagrabiae: Academia Scientiarum et Artium Slavorum Meridionalium.

Frenkel, Yehoshua. 1999. Political and Social Aspects of Islamic Religious Endowments (awqāf): Saladin in Cairo (1169-73) and Jerusalem (1187-93). Bulletin of the School of Oriental and African Studies 62: 1-20. Https://doi. org/10.1017/s0041977x00017535.
Hoško, Franjo Emanuel, Pejo Ćošković, Vicko Kapitanović, eds. 2010. Hrvatski franjevački biografski leksikon. Zagreb: Leksikografski zavod Miroslav Krleža, Vijeće franjevačkih zajednica Hrvatske i Bosne i Hercegovine.

Ibn Wāṣil, Ğamāluddīn. 1975. Mufarriğ al-kurūb fì 'ahbār Banī 'Ayyūb. al-Iskandariyya: al-Hay'a al-mi riyya al-'̄̄mma li al-kutub.

Jablanović, Dr. Ivan. 1031. Bosanski grofovi Brankovići. Napredak: Glasilo Hrvatskog kulturnog društva "Napredak" u Sarajevu. 5-6: 65-68.

Klaić, Vjekoslav. 1914. Život i djela Pavla Rittera Vitezovića, Zagreb: Matica hrvatska.

Kudelić, Zlatko. 2010. Čaplovičeva povijest Marčanske biskupije. Povijesni prilozi 38: 135-182.

Lujić, Božo. 20111. Franjin duh u svetoj zemlji. Glasnik svetog Ante 19: 4-5.

Picirillo, Michele, ed. 2006. Registrum equitum SSmi Sepulchri D.N.J.C. (1561-1848): manoscritti dell' Archivio storico della Custodia di Terra Santa a Gerusalemme, Studium Biblicum Franciscanum, Collectio Maior, 46. Jerusalem; Milano: Custodia di Terra Santa.

Pringle, Denys. 2007. The Churches of the Crusader Kingdom of Jerusalem, Vol. 3, Cambridge: Cambridge University Press.

Rabāya 'a, Ibrāhīm. 2008. Ṭā’ifa al-Yahūd fī madīna al-Quds min bidāyāt al- ukm al-'Uțmānī hạattā qiyām al-ḥaraka al- ahyūniyya. al-Mağalla al-'Urduniyya li al-tārīh wa al-'ātār. 2, No. 2: 100-127.

Radnich Baçanin, Fra Mihaylo. 1683. Pogargegne izpraznosti od sviyeta: $\mathrm{u}$ trii diela razdiegleno - De contemptu vanitatum mundi: libri tres, illirico idiomate. Romae: Ex Typographia Christophori Dragondelli.

Radonić,Jovan. 1911. Grof Đorđe Branković i njegovo vreme. Beograd: Srpska kraljevska akademija. 
Radonić, Jovan. 1939. Od prve opsade Beča do Velike Seobe. In: Vojvodina od najstarijih vremena do Velike Seobe, ed. Dušan J. Popović, Novi Sad, Istorijsko društvo u Novom Sadu. 518-519.

Schwicker, Johann Heinrich. 1875. »Zur Geschichte der kirchlichen Union in croatischen Militärgänze: Eine geschichtliche Studie". Archiv fur osterreichische Geschichte. Wien: Kaiserlichen Akademie der Wissenchaften.

Sekulić, Ante. 1991. Bački Hrvati: Narodni Život i običaji, Zbornik za narodni život i običaje Južnih Slavena, knjiga 52. Zagreb: JAZU.

Siğill Mahkama al-Quds al-šar'iyya, No. 184, 1092. h/1681. 35-36.

Subkī (al), al-Imām Abū al-Ḥasan Taqiyyyuddīn 'Abd al-Kāfì. s. a. Fatāwā al-Subkī. Bayrūt: Dār al-Ma'rifa.
Šafiq Bāšā, Muḥammad. 1344 AH. al-Hikr wa taqdīruh. al-Qāhira: Ma ba'a Miṣr.

Taloci, Lauš. 1889. (Izvorni naslov: Lažni Brankovići), Lažni Brankovići od Lauša Talocija. (translated from Hungrian by dr. St. Pavlović). Letopis Matice srpske. 1889: 54-83.

Tóth, István György. 2002. Franjevci Bosne Srebrene kao misionari u turskoj Ugarskoj (1584-1716.) [Bosnian Franciscan missionaries in Turkish Hungary]. Scrinia Slavonica 2, No. 1: 178-201.

Vasiljev, Spasoje. 1949. Književnost bačkih Bunjevaca u 17. i 18. veku. Glasnik Istorijskog društva u Novom Sadu. 1-14.

Vitković, Gavrilo, ed. 1875. Spomenici iz Budimskog i Peštanskog arhiva. In: Glasnik Srpskog učenog društva (6). Beograd. 